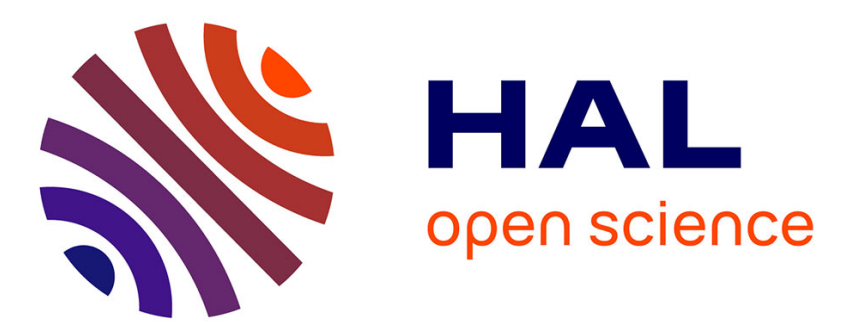

\title{
Amperometric tyrosinase based biosensor using an electrogenerated polythiophene film as an entrapment support
}

\author{
Christophe Védrine, Silvia Fabiano, Canh Tran-Minh
}

\section{To cite this version:}

Christophe Védrine, Silvia Fabiano, Canh Tran-Minh. Amperometric tyrosinase based biosensor using an electrogenerated polythiophene film as an entrapment support. Talanta, 2003, 59 (3), pp.535-544. 10.1016/S0039-9140(02)00540-4 . emse-00520263

\section{HAL Id: emse-00520263 \\ https://hal-emse.ccsd.cnrs.fr/emse-00520263}

Submitted on 15 Oct 2010

HAL is a multi-disciplinary open access archive for the deposit and dissemination of scientific research documents, whether they are published or not. The documents may come from teaching and research institutions in France or abroad, or from public or private research centers.
L'archive ouverte pluridisciplinaire HAL, est destinée au dépôt et à la diffusion de documents scientifiques de niveau recherche, publiés ou non, émanant des établissements d'enseignement et de recherche français ou étrangers, des laboratoires publics ou privés. 


\title{
Amperometric tyrosinase based biosensor using an electrogenerated polythiophene film as an entrapment support
}

\author{
Christophe VÉdrine(1), SilVia FABIANO(1), CANH Tran-MinH(1)*
}

(1) Ecole Nationale Supérieure des Mines de Saint Etienne, Centre SPIN ; Département PMMC ; LPMG, UMR CNRS 5148, 158 Cours Fauriel ; 42023 Saint-Étienne Cedex 2, France

\begin{abstract}
An amperometric enzyme sensor using tyrosinase, also called polyphenol oxidase (PPO), was constructed for determination of phenolic compounds and herbicides. The enzyme was entrapped in a conducting polymer, poly 3,4-ethylenedioxythiophene (PEDT), electrochemically generated on a glassy carbon electrode. Several experimental parameters in the electropolymerisation process and working conditions were determined to optimise biosensor performances. Mono-phenol and di-phenol were tested in oxygenated solutions, by amperometric measurements at $-200 \mathrm{mV}$ (vs. SCE) in a batch system. The limit of detection of these molecules ranges from 5 to $500 \mathrm{nM}$. Detection of herbicides was obtained from the inhibition of tyrosinase electrode responses. The limit of detection for atrazine and diuron was 1 and $0.5 \mathrm{mg} \mathrm{l}^{-1}$ respectively. These data suggest that PEDT film is a promising PPO immobilisation method.
\end{abstract}

Keywords:

Conducting polymer; Tyrosinase; Phenolic compounds; Herbicides

\section{Introduction}

Biosensors are devices capable of recovering analytical information by utilising biological component as part of the sensor [1]. The use of an amperometric enzyme electrode provides a promising way of development of a wide range of biosensors. This approach combines specificity of the biocomponent (selective molecular recognition) with advantages of electrochemical detection [2].

The essential task in construction of an amperometric biosensor is to efficiently and effectively immobilise the bioactive moiety onto the electrode surface. Electrochemical polymerisation of conducting polymer is a simple one-step process to construct bioelectrodes. Moreover, this immobilisation method allows to easily control the thickness of enzyme film [1 and 3].

The ability to synthesise conductive electroactive polymers under mild conditions enables to perform the immobilisation of a range of biological moieties (enzymes, antibodies, even whole living cells...). Many conducting polymers can be electrochemically generated [4]. In most polymers such as polypyrrole [5, 6, 7 and 8], polyaniline [9, 10 and 11] and polythiophene [12 and 13], redox charges are delocalised over some polymer groups that could facilitate the oxidation-reduction processes.

Polypyrroles can be formed under mildly oxidative conditions from aqueous media. Polyanilines are formed from similar conditions, although formation of the most highly conducting form requires the presence of acid. The monomers of simple polythiophenes are

\footnotetext{
${ }^{*}$ Corresponding author: tran@emse.fr
} 
not water-soluble. Among the promising family of polythiophenes, poly 3,4ethylenedioxythiophene (PEDT) shows remarkable stability, provides homogeneous films [14] and can be synthesised electrochemically even in aqueous medium [15]. Unlike pyrrole, 3,4ethylenedioxythiophene monomer (EDT) does not require distillation before use. Previous works [16 and 17] showed the interest of using PEDT as a support for glucose oxidase (GOD) immobilisation.

Tyrosinase is a binuclear copper containing metalloprotein and catalyses, in the presence of molecular oxygen, the hydroxylation and oxidation of mono-phenols to o-quinones (monophenolase activity) and the oxidation of o-diphenols to o-quinones (diphenolase activity) [18]. This enzyme, produced from mushrooms, has an isoelectric point of 4.5 [19] and carries a negative charge for $\mathrm{pH}>4.5$ in aqueous solution. Attractive electrostatic interactions can occur with PEDT that is positively charged [15 and 20].

The PEDT/PPO biosensor is based on the detection of the electrochemical reduction at $-0.2 \mathrm{~V}$ of o-quinone enzymatically produced. Thus o-diphenol electrochemically generated can undergo another enzymatic oxidation. It leads to a local increase of the concentration of odiphenol [21]. This amplification mechanism explains high sensitivities of mono-phenol or odiphenol detection with tyrosinase based bioelectrode. It was also reported that triazine and phenyl-urea herbicides could be determined from inhibition of tyrosinase response to a substrate [22, 23 and 24].

The present work describes a tyrosinase based biosensor. It attempts to demonstrate the potentialities of the PEDT immobilisation technique for analytical applications using tyrosinase (which has a more complex action mechanism than GOD). Some molecules of medical interest and pollutants potentially present in the environment were tested using this biosensor.

\section{Experimental}

\section{II.1. Reagents}

EDT was kindly provided by Bayer AG (France). Polyethylene glycol (PEG) of 15 ooo MW was purchased from Aldrich. Tyrosinase (polyphenol oxidase, PPO) (EC 1.14.18.1, $6680 \mathrm{U} \mathrm{mg}^{-1}$ lot 109H7037) from mushroom was procured from Sigma (France).

Catechol, dopamine, epinephrine, L-dopa, p-cresol, 3-chlorophenol, 4-chlorophenol were purchased from Sigma. Phenol was obtained from Carlo Erba.

The following herbicides (Pestanal ${ }^{\circledR}$ ): atrazine [2-ethylamino-4-chloro-6-isopropyl amino1,3,5 triazine], diuron [3(3,4-dichlorophenyl)1,1 dimethylurea], were purchased from Riedelde-Haen (France). They were prepared in anhydrous ethanol (HPLC grade, Carlo Erba) to get $10 \mathrm{~g} \mathrm{l}^{-1}$ stock solutions which were stored in darkness at $4{ }^{\circ} \mathrm{C}$ for 1 month.

All other chemicals were of analytical grade. Phosphate buffer was prepared using di-sodium hydrogen phosphate and sodium di-hydrogen phosphate (Prolabo, France). All solutions were prepared using milliQ ${ }^{\circledR}$ pure water (Millipore, France).

\section{II.2. Apparatus}

Voltammetric and amperometric measurements were performed using a Tacussel PGP 201 potentiostat. The potentiostat output was recorded and processed by means of a VOLTA-MASTER 1 software. The electrochemical cell was a three-electrode cell where the PEDT/PPO modified glassy carbon disk electrode acted as the working electrode and a platinum wire as the counter electrode. All potentials were measured vs. SCE. The working electrodes were constructed using a BAS ${ }^{\circledR}$ glassy carbon electrode with a disk-shaped active surface of $3 \mathrm{~mm}$ diameter. Diamond fluid kit was provided by BAS ${ }^{\circledR}$ (England) to polish the electrode surface.

\section{II.3. Immobilisation procedure}

Bare electrodes used for preparing the biosensors consisted of glassy carbon disks. The working electrode surface was polished before use with diamond solution of $15 \mu \mathrm{m}$, then $3 \mu \mathrm{m}$ and finally $1 \mu \mathrm{m}$ particle size. At last, it was carefully rinsed with distilled water.

Two immobilisation procedures were used (Figure 1). 


\section{II.3.1. Method A, for direct determination of substrates}

The electropolymerisation solution was prepared from $1 \mathrm{mg}$ of tyrosinase dissolved in $200 \mu \mathrm{l}$ of a $10^{-2} \mathrm{M}$ EDT aqueous solution. Five microlitres of this solution were deposited on a glassy carbon disk and dried at room temperature.

The dry electrode was dipped in a PEG $10^{-3} \mathrm{M}$ phosphate buffer solution (o.02 M, pH 6.2) and the EDT electropolymerisation was carried out using a $+1200 \mathrm{mV}$ constant potential for 2 min.

\section{II.3.2. Method B, for determination of inhibitors}

The electrode was dipped in a $0.02 \mathrm{M} \mathrm{pH} 6.2$ phosphate buffer solution containing $10^{-2} \mathrm{M}$ of EDT, $10^{-3} \mathrm{M}$ of PEG and $5 \mathrm{mg} \mathrm{ml}^{-1}$ of tyrosinase. Electrochemical growth of PEDT was carried out using a $+1200 \mathrm{mV}$ constant potential for $2 \mathrm{~s}$.

\section{II.4. Measurements}

Amperometric measurements of substrates and inhibitors, with the PEDT/PPO biosensor were carried out in a $20 \mathrm{ml}$ beaker containing $10 \mathrm{ml}$ of phosphate buffer solution (o.1 M, pH 6.5). The electrochemical cell was completed with a SCE reference electrode and a platinum wire counter electrode. The solution was continuously stirred in the open air with a magnetic stirrer to maintain a constant oxygen concentration in the solution for the enzymatic reaction to operate properly. The temperature was controlled using a thermostat (Lauda-Thermostat, Germany).

For substrates determination a potential of $-200 \mathrm{mV}$ was applied to the working electrode to detect o-quinone formation. When a baseline was stable, substrate was spiked. The current generated on the biosensor was measured when steady state was reached.

For determination of inhibitors, dopamine $25 \mu \mathrm{M}$ was used as a substrate, when the current was stable the inhibitor was spiked and the current decrease was measured.

Since tyrosinase catalyses the oxidation of several mono-phenols and o-diphenols to oquinones in the presence of oxygen, its concentration should be kept constant because it is a co-substrate of the enzymatic reaction.

Unless otherwise stated all experiments were carried out at $25{ }^{\circ} \mathrm{C}$ with an applied potential of $-200 \mathrm{mV}$ vs. SCE, in a phosphate buffer (0.1 M, pH 6.5) containing 0.1 M KCl.

\section{Results and discussion}

Several immobilisation methods have been used to construct PPO based biosensors (Table 1). Entrapment of PPO in a PEDT film is an easy and fast immobilisation method. There is no need to synthesise the monomer since it is commercially available. This polymer is directly electrogenerated on a glassy carbon electrode. Contrary to cryo-hydrogel or silica-gel immobilisation methods, it does not require any incubation step in a specific solution or in defined temperature conditions.

PEDT/PPO electrodes were constructed according to two methods. Electrodes prepared with the method A were used to detect substrates. Biosensors constructed with method B were used for inhibitor determination. The main difference between these two methods lies in the film thickness achieved.

\section{III.1. Substrate determination}

\section{III.1.1. Optimisation of the enzyme immobilisation}

Method A (Figure 1) was used to achieve entrapment of tyrosinase for phenolic compound determination.

The influence of enzyme loading in the polymer on the sensor response to $5 \mu \mathrm{M}$ catechol was examined (Figure 2, solid line). Response increases when the amount of enzyme deposited on the electrode increases from 5 to $25 \mu \mathrm{g}$. At higher amount of deposited enzyme, response decreases. O-quinone production takes place mostly at the region closer to the film/solution interface. Therefore, most of o-quinone molecules produced in this way are diluted in the bulk solution hence their transfer to the electrode surface is decreased. Similar behaviour was reported for polypyrrole-GOD electrode [25]. 
The optimal amount of enzyme ( $25 \mu \mathrm{g})$ was used to assess the effect of electropolymerisation time. While $5 \mathrm{~s}$ of electropolymerisation time were found sufficient to ensure maximal response (Figure 3, solid line). It was observed that in this case the film was fragile, friable and could easily be detached from the electrode during handling. With $2 \mathrm{~min}$ electropolymerisation corresponding to complete polymerisation of the polymer, a more adherent film is obtained. Biosensor response decreases slightly. It is probably caused by the diffusional limitation of a polymeric layer.

\section{III.1.2. Effects of $\mathrm{pH}$ and temperature on the biosensor response to catechol}

Appropriate $\mathrm{pH}$ ensures efficient entrapment of the enzyme while preventing loss of its activity under electropolymerisation conditions. An optimal $\mathrm{pH}$ of 6.2 was used: the same $\mathrm{pH}$ had previously been used for PEDT electropolymerisation [17].

Working $\mathrm{pH}$, corresponding to the amperometric response of the PEDT/PPO electrode to catechol $5 \mu \mathrm{M}$ was also investigated for pHs ranging from 5 to 8 in $0.1 \mathrm{M}$ phosphate buffer solution (Figure 4). Maximal response is obtained for $\mathrm{pH}$ 6.5. This agrees with data reported by Cosnier and Innocent [26] for a bioelectrode using a polypyrrole tyrosinase film.

Effects of temperature on the enzyme electrode were studied with $5 \mu \mathrm{M}$ catechol at temperature ranging from 15 to $40^{\circ} \mathrm{C}$ (Figure 4). The biosensor response increases with temperature from 15 to $25^{\circ} \mathrm{C}$ then a decrease is observed. The optimal temperature $25{ }^{\circ} \mathrm{C}$ also corresponds to the biosensor maximal enzyme activity.

\section{III.1.3. Long-term stability}

The main objective of enzyme immobilisation on a transducer, for analytical purposes, is to stabilise the enzyme for the biosensor to be used repeatedly over a long period of time. The long-term stability of the biosensor was monitored by measuring its response to $5 \mu \mathrm{M}$ catechol solution everyday. The PEDT/PPO electrode was washed and stored, between measurements, at $4{ }^{\circ} \mathrm{C}$ in phosphate buffer solution. The enzyme electrode retained about 30 $\%$ of its initial activity after 12 days (Figure 5).

\section{III.1.4. Response of the biosensor to different substrates}

The two catalytic activities of tyrosinase (monophenolase and diphenolase) were tested using mono-phenolic and o-diphenolic compounds [27].

\section{III.1.4.1. Detection of o-diphenols}

Responses of the tyrosinase sensor to o-diphenols was first investigated. After each addition of aliquots of the catechol stock solution into air-saturated phosphate buffer solution the signal reaches a stable plateau, so that a calibration curve can be plotted (Figure 6). Doseresponse curves for dopamine, epinephrine, -dopa are also shown in this figure. Sensitivity corresponding to the linear range for catechol, dopamine, -dopa, epinephrine are about 1999, 133, 104, $56 \mathrm{~mA} \mathrm{M}^{-1} \mathrm{~cm}^{-2}$ respectively. This sensitivity gradually decreases at higher substrate concentrations. The same sensitivity order was reported by Cosnier and Innocent [26], and Besombes et al. [28]. The PEDT/PPO electrode sensitivity to dopamine is 2.2 times higher than that of polypyrrole/PPO electrode [29].

Tyrosinase exhibits a particular behaviour for $\mathrm{L}_{\text {-dopa }}$ as a substrate. Sensitivity to $\mathrm{L}_{\text {-dopa }}$ detection is higher than to epinephrine for low concentrations. At higher concentrations, sensitivity to epinephrine is better compared to ${ }_{\mathrm{L}}$-dopa. Duckworth and Coleman [30] and Pomerantz and Warner [31] reported that two apparent values of $\mathrm{Km}$ for ${ }_{\mathrm{L}}$-dopa have been observed (two order of magnitude of difference). These data could explain the particular behaviour of the PEDT/PPO electrode when ${ }_{\mathrm{L}}$-dopa is used.

\section{III.1.4.2. Detection of mono-phenols}

Calibration curves obtained for mono-phenolic compounds vary in sensitivities depending on the analyte involved (Figure 7). Sensitivities (calculated in the linear range) decrease in this order: p-cresol $>4$-chlorophenol $>$ phenol $>3$-chlorophenol. The main characteristics of the biosensor including sensitivity, linear range and detection limit are listed in Table 2. 
The overall high sensitivity of the PEDT/PPO electrode compared to PPO biosensors using other matrices can be attributed to the biocompatible microenvironment for the enzyme. The difference in sensitivity between each mono-phenolic compound might depend on the hydrophobic characteristics of the immobilisation matrix [32] and molecular steric hindrance. In fact, 3-chlorophenol showed only a weak response. Transition state of this compound is difficult to form because of large steric restriction [33]. Polypyrrole/PPO bioelectrode showed similar detection profile towards chlorinated compounds. Moreover, sensitivities of PEDT/PPO electrodes towards phenol, 4-chlorophenol, 3-chlorophenol are 2.5, 3.8, o.7 times of the polypyrrole/PPO electrode detection sensitivities respectively [34]. Compared to a solgel/PPO electrode described by Wang et al. [35], our electrode is 5.6 and 3.3 times more sensitive towards p-cresol and phenol respectively.

No significant difference of response time has been observed for o-diphenolic and monophenolic compounds. While a time-lag is necessary for the sample solution to be homogeneous after substrate addition, a 20-40 s response of the PEDT/PPO biosensor is observed for any substrate. This response time is consistent with results reported by Wang et al. [35].

\section{III.2. Determination of inhibitors}

Detection of atrazine by inhibition of a tyrosinase bioelectrode has already been reported [22]. Atrazine acts as a competitive inhibitor on the enzyme active site [28]. Similar inhibition with phenyl-urea herbicides was observed by McArdle and Persaud [22]. Since diuron is a phenylurea herbicide, both inhibitory effects of atrazine and diuron were determined with the PEDT/PPO electrode.

Bioelectrodes prepared using the electropolymerisation method A did not show any inhibition when they were incubated with atrazine or diuron. Numbers of parameters act on the PEDT/PPO electrode behaviour such as inhibitor, substrate, and product diffusion, kinetic of immobilised tyrosinase, polymer film permeability [36]. For instance, Wang et al. [37] showed that the thicker the polymer film the lower the permeability.

A new electropolymerisation method B was adopted to reduce the polymer film thickness while maintaining enough enzyme for a significant response (Figure 1). Since tyrosinase to catechol affinity is higher than to dopamine [38 and 39], this latter substrate was used for inhibitor determination.

The influence of enzyme loading in the polymer on the sensor response to $25 \mu \mathrm{M}$ dopamine was examined (Figure 2, dashed line). Similar results were observed with method A. Optimal response is achieved when the enzyme solution concentration is $5 \mu \mathrm{g} \mu \mathrm{l}^{-1}$. Two seconds of electropolymerisation were found optimal to ensure maximal response (Figure 3, dashed line). It is the best compromise between thickness and amount of immobilised enzyme.

The enzyme chemical environment is the same for both methods A and $\mathrm{B}$. It was assumed $\mathrm{pH}$ and temperature optimisation performed on PEDT/PPO electrodes (method A) was still valid for bioelectrodes prepared according the method $\mathrm{B}$. Inhibition tests were carried out using the following conditions: $25 \mu \mathrm{M}$ dopamine, $0.1 \mathrm{M}, \mathrm{pH} 6.5$ sodium phosphate buffer and $0.1 \mathrm{M}$ $\mathrm{KCl}, 25{ }^{\circ} \mathrm{C},-200 \mathrm{mV}$ vs. SCE.

Calibration curves for atrazine and diuron are reported in Figure 8. These results agree with those given by other authors [22, 28 and 40]. Diuron has a greater inhibitory action than atrazine on tyrosinase electrode, which is consistent with detection limits 0.5 and $1 \mathrm{mg} \mathrm{l}^{-1}$ respectively.

\section{Conclusion}

In conclusion, tyrosinase can effectively be immobilised in PEDT electrogenerated film to produce sensitive biosensors. Optimisation of temperature and $\mathrm{pH}$ enables the biosensor to detect mono-phenolic and o-diphenolic compounds as substrates with high sensitivity and fast response. Compared to osmium hydrogel film, poly-pyrrole amphiphilic, cryo-hydrogel, silica sol-gel based biosensor, sensitivity of phenol detection of the PEDT/PPO electrode is higher than other unmediated immobilisation methods (Table 1). 
Detection of herbicides (atrazine, diuron) by enzyme inhibition has also been achieved at $\mu \mathrm{M}$ concentration levels. These results are in agreement with those reported by Besombes et al. [28] and Wang et al. [40].

Further investigations are required to achieve detection limits of $0.1 \mathrm{nM}$ for catecholamine

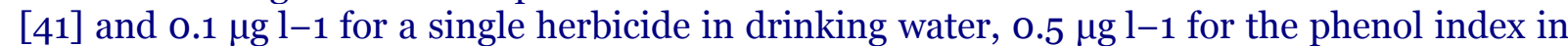
water required for medical and environmental applications respectively. The use of mediators would lower detection limits and reduce interferences [27]. Long-term stability could also be improved under dry storage conditions. Biosensors miniaturisation and incorporation in a flow-injection-analysis system are currently underway.

\section{References}

[1] G.G. Wallace, M. Smyth and H. Zhao Trends Anal. Chem. 18 (1999), p. 245.

[2] P.N. Bartlett and R.G. Whitaker J . Electroanal. Chem. 224 (1987), p. 27.

[3] P.N. Bartlett and R.G. Whitaker J . Electroanal. Chem. 224 (1987), p. 37.

[4] S.A. Emr and A.M. Yacynych Electroanalysis 7 (1995), p. 913.

[5] S. Cosnier and A. Lepellec Electrochim. Acta 44 (1999), p. 1833.

[6] S. Cosnier Electroanalysis 9 (1997), p. 894.

[7] D. Bélanger, J. Nadreau and G. Fortier J. Electroanal. Chem. 274 (1989), p. 143.

[8] G. Fortier, E. Brassard and D. Bélanger Biosens. Bioelectron. 5 (1990), p. 473.

[9] M. Trojanowics, O. Geschke, T. Krawczynski vel Krawczyk and K. Cammann Sens. Actuat. B 28 (1995), p. 191.

[10] S. Mu and H. Xue Sens. Actuat. B 31 (1996), p. 155.

[11] S.-Y. Lu, C.-F. Li, D.-D. Zhang, Y. Zhang, Z.-H. Mo, Q. Cai and A.-R. Zhu J. Electroanal. Chem. 364 (1994), p. 31.

[12] M. Hiller, C. Kranz, J. Huber, P. Bäuerle and W. Schuhmann Adv. Mater. 8 (1996), p. 219.

[13] G. Zotti, S. Zecchin and G. Schiavon Chem. Mater. 7 (1995), p. 2309.

[14] H. Yamato, M. Ohwa and W. Wernet J. Electroanal. Chem. 397 (1995), p. 163.

[15] S. Garreau, G. Louarn, J.P. Buisson, G. Froyer and S. Lefrant Macromolecules 32 (1999), p. 6807.

[16] B. Piro, L.A. Dang, M.C. Pham, S. Fabiano and C. Tran-Minh J . Electroanal. Chem. 512 (2001), p. 101.

[17] S. Fabiano, C. Tran-Minh, B. Piro, L.A. Dang, M.C. Pham, O. Vittori, Mater. Sci. Eng. C21 (2002) 61-67.

[18] H. Decker and F. Tuczek Trends Biochem. Sci. 25 (2000), p. 392.

[19] Y.A.M. Gerritsen, C.G.J. Chapelon and H.J. Wichers Phytochemistry 35 (1994), p. 573.

[20] M.A. Khan and S.P. Armes Langmuir 15 (1999), p. 3469.

[21] S. Cosnier and C. Innocent J. Electroanal. Chem. 328 (1992), p. 361.

[22] F.A. McArdle and K.C. Persaud Analyst 118 (1993), p. 419.

[23] A. Hipólito-Moreno, M.E. León-Gonzalez, L.V. Pérez-Arribas and L.M. Polo-Diez Anal. Chim. Acta 362 (1998), p. 187.

[24] C. Nistor and J. Emnéus Waste Manage. 19 (1999), p. 147.

[25] M.-C. Shin and H.-S. Kim Anal. Lett. 28 (1995), p. 1017.

[26] S. Cosnier and C. Innocent Bioelectrochem. Bioenerg. 31(1993), p. 147.

[27] M. Hedenmo, A. Narváez, E. Domínguez and I. Katakis J. Electroanal. Chem. 425 (1997), p. 1.

[28] J.-L. Besombes, S. Cosnier, P. Labbé and G. Reverdy Anal. Chim. Acta 311 (1995), p. 255.

[29] S. Cosnier, C. Innocent, L. Allien, S. Poitry and M. Tsacopoulos Anal. Chem. 69 (1997), p. 968.

[30] H.W. Duckworth and J.E. Coleman J . Biol. Chem. 7 (1970), p. 1613.

[31] S.H. Pomerantz and M.C. Warner J. Biol. Chem. 242 (1967), p. 5308.

[32] J. Wang, F. Lu and L. David Analyst 119 (1994), p. 455.

[33] N. Kitajima and Y. Moro-oka Chem. Rev. 94 (1994), p. 737. 
[34] J.L. Besombes, S. Cosnier, P. Labbé and G. Reverdy Anal. Lett. 28 (1995), p. 405.

[35] B. Wang, J. Zhang and S. Dong Biosens. Bioelectron. 15 (2000), p. 397.

[36] P.N. Bartlett and J.M. Cooper J . Electroanal. Chem. 362 (1993), p. 1.

[37] J. Wang, S.-P. Chen and M.S. Lin J . Electroanal. Chem. 273 (1989), p. 231.

[38] J. Wang and M.S. Lin Anal. Chem. 60 (1988), p. 1545.

[39] L.G. Fenoll, J.N. Rodríguez-López, F. García-Molina, F. García-Cánovas and J. Tudela Int. J . Biochem. Cell B 34 (2002), p. 332.

[40] J. Wang, V.B. Nascimento, S.A. Kane, K. Rogers, M.R. Smyth and L. Angnes Talanta 43 (1996), p. 1903.

[41] T. Okumura, Y. Nakajima, M. Matsuoka and T. Takamatsu J. Chromatogr. B 694 (1997), p. 305.

[42] Q. Deng, Y. Guo and S. Dong Analytica Chimica Acta 319 (1996), p. 71.

\section{Figures}

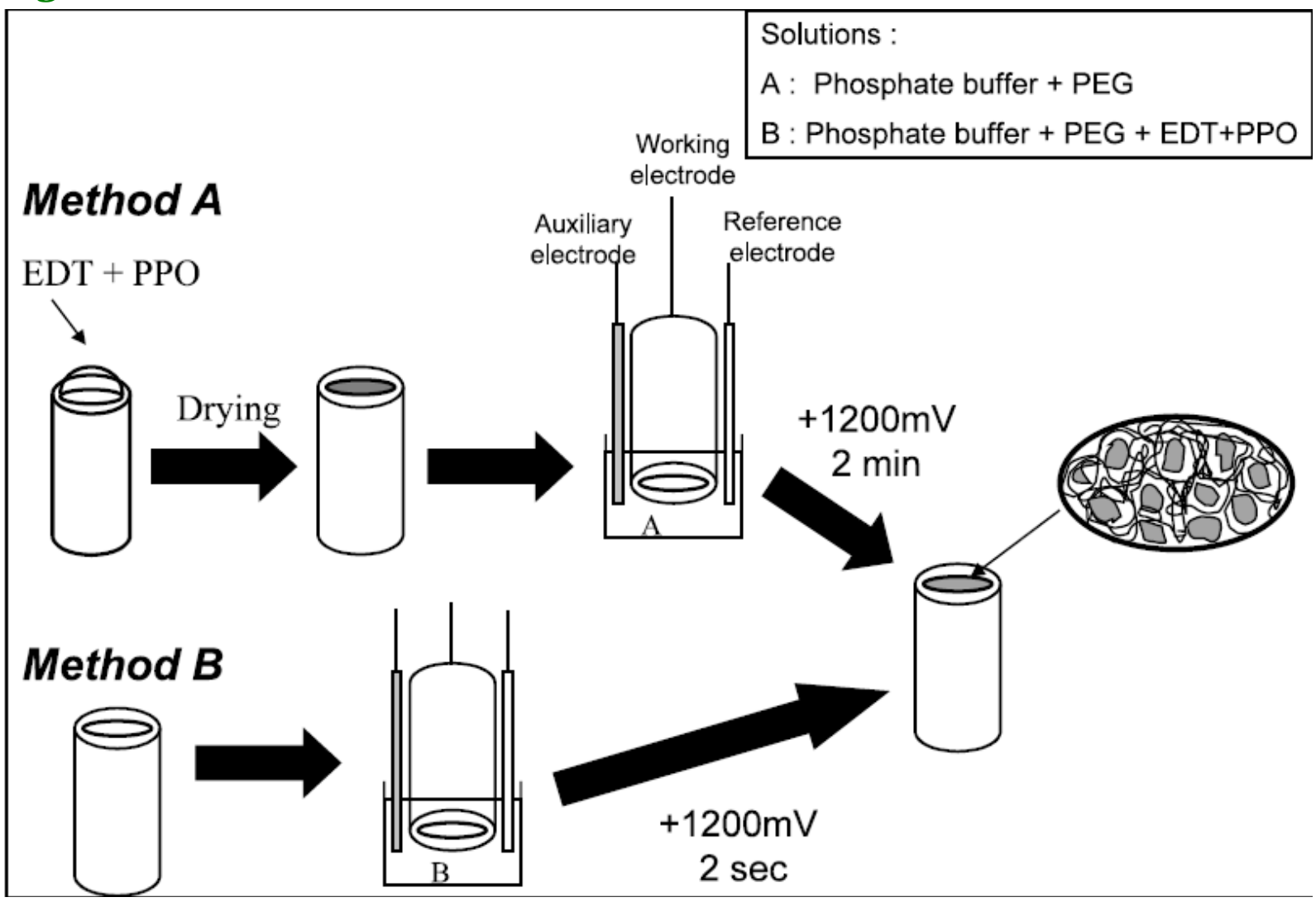

Figure 1: Immobilisation methods for preparation of PEDT/ PPO electrode. Method (A) for direct determination of mono-phenolic and o-diphenolic compound and method (B) for inhibitor determination. 


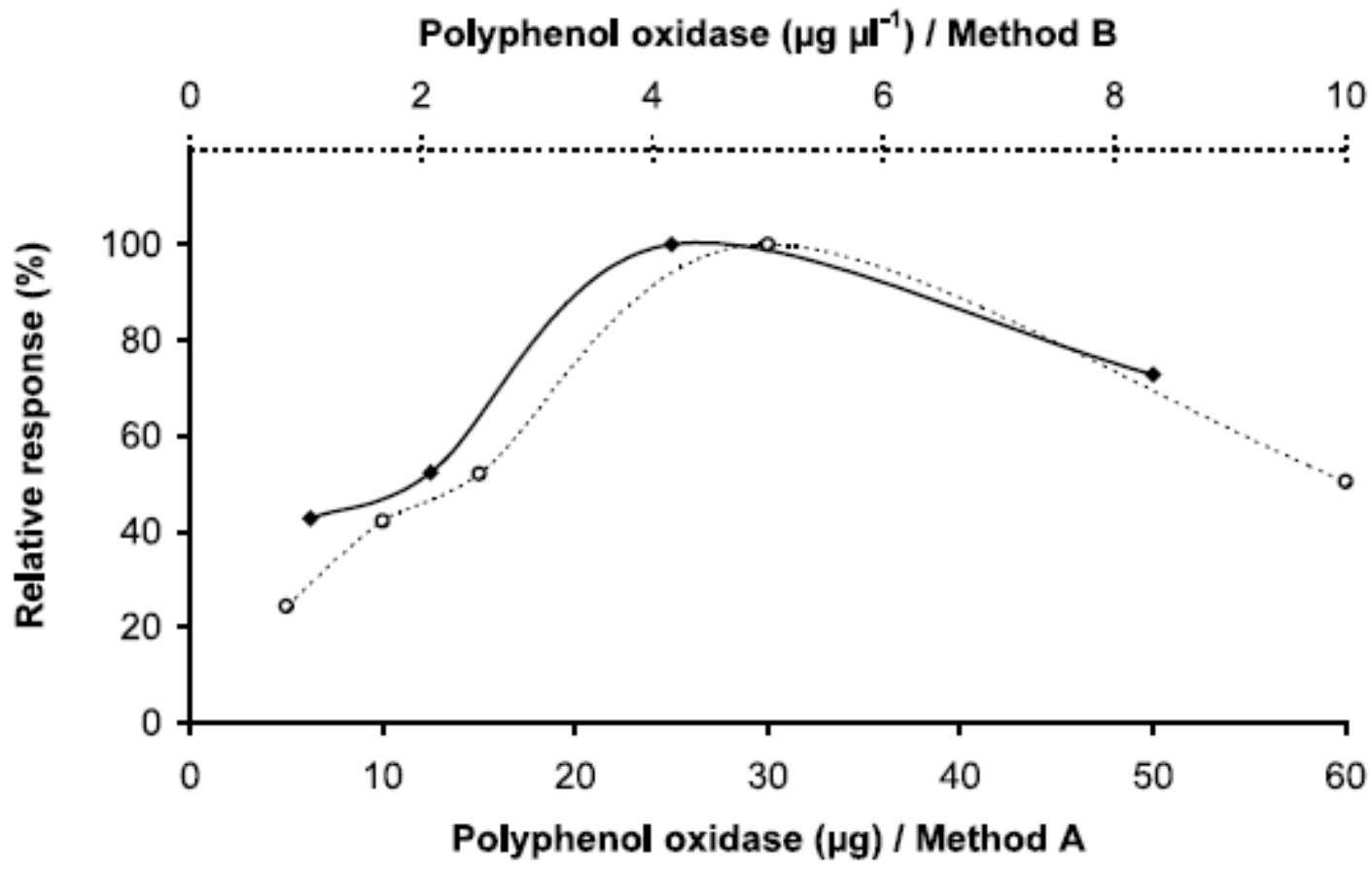

Figure 2: Effect of enzyme loading on PEDT/PPO electrode response to $5 \mu \mathrm{M}$ catechol ( $\longrightarrow$ ) using preparation method A (2 min of electropolymerization) and to $25 \mathrm{mM}$ dopamine (-----) using preparation method B (2 s of electropolymerization). Conditions: $0.1 \mathrm{M}, \mathrm{pH} 6.5$ sodium phosphate buffer and $0.1 \mathrm{M} \mathrm{KCl}, 258 \mathrm{C},-/ 200 \mathrm{mV}$ vs. SCE.

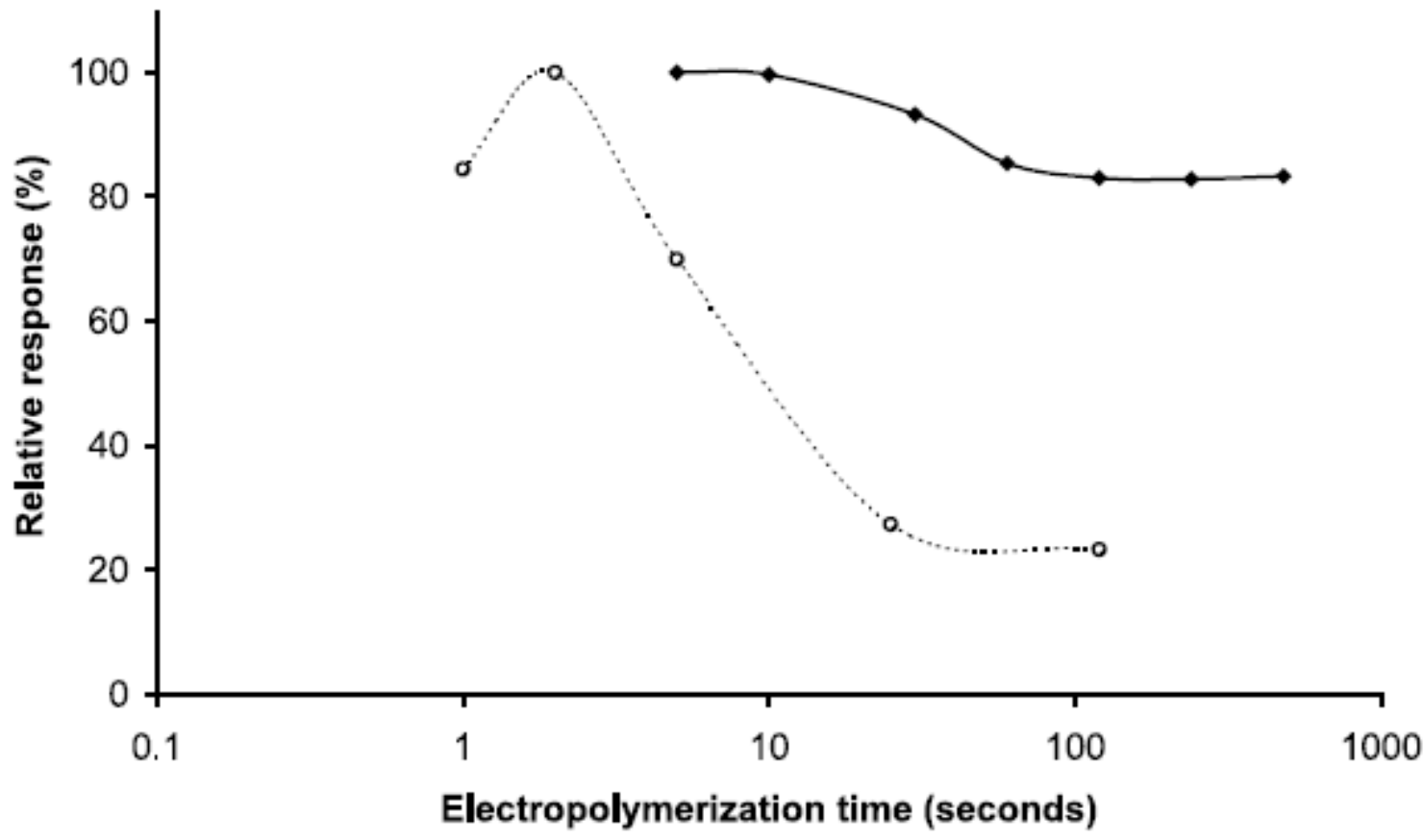

Figure 3: Effect of electropolymerization time on PEDT/ PPO electrode response to $5 \mu \mathrm{M}$ catechol (- $-/)$ using preparation method A and to $25 \mathrm{mM}$ dopamine (-----) using preparation method B. Conditions: $0.1 \mathrm{M}, \mathrm{pH} 6.5$ sodium phosphate buffer and $0.1 \mathrm{M} \mathrm{KCl}, 258 \mathrm{C}$, -/ $200 \mathrm{mV}$ vs. SCE. 


\section{Temperature $\left({ }^{\circ} \mathrm{C}\right)$}

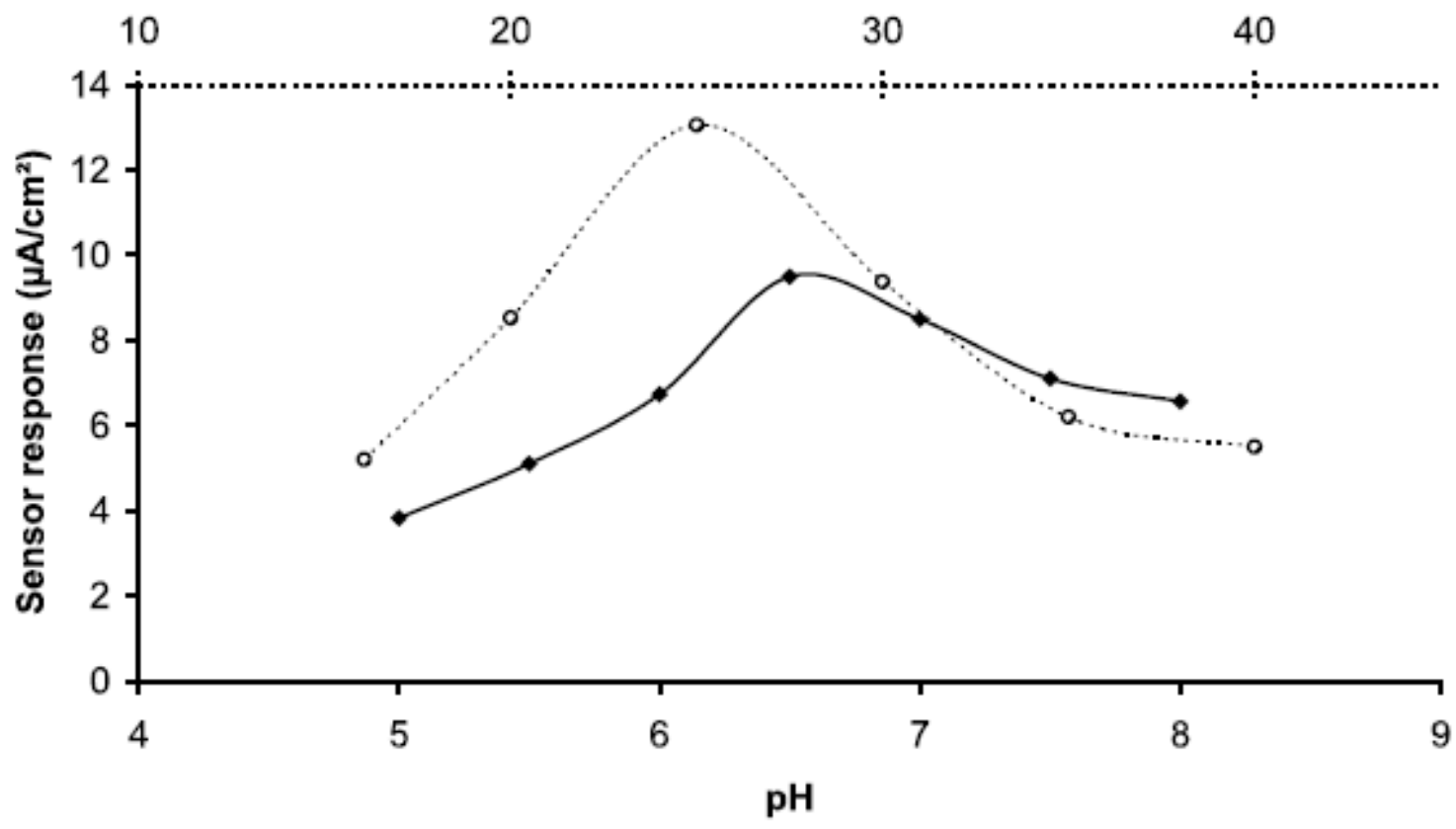

Figure 4: Effect of temperature (-----) and working pH ( $\longrightarrow$ on PEDT/PPO electrode response to $5 \mu \mathrm{M}$ catechol using preparation method A. Conditions: $0.1 \mathrm{M}$ sodium phosphate buffer and $0.1 \mathrm{M} \mathrm{KCl},-/ 200 \mathrm{mV}$ vs. SCE.

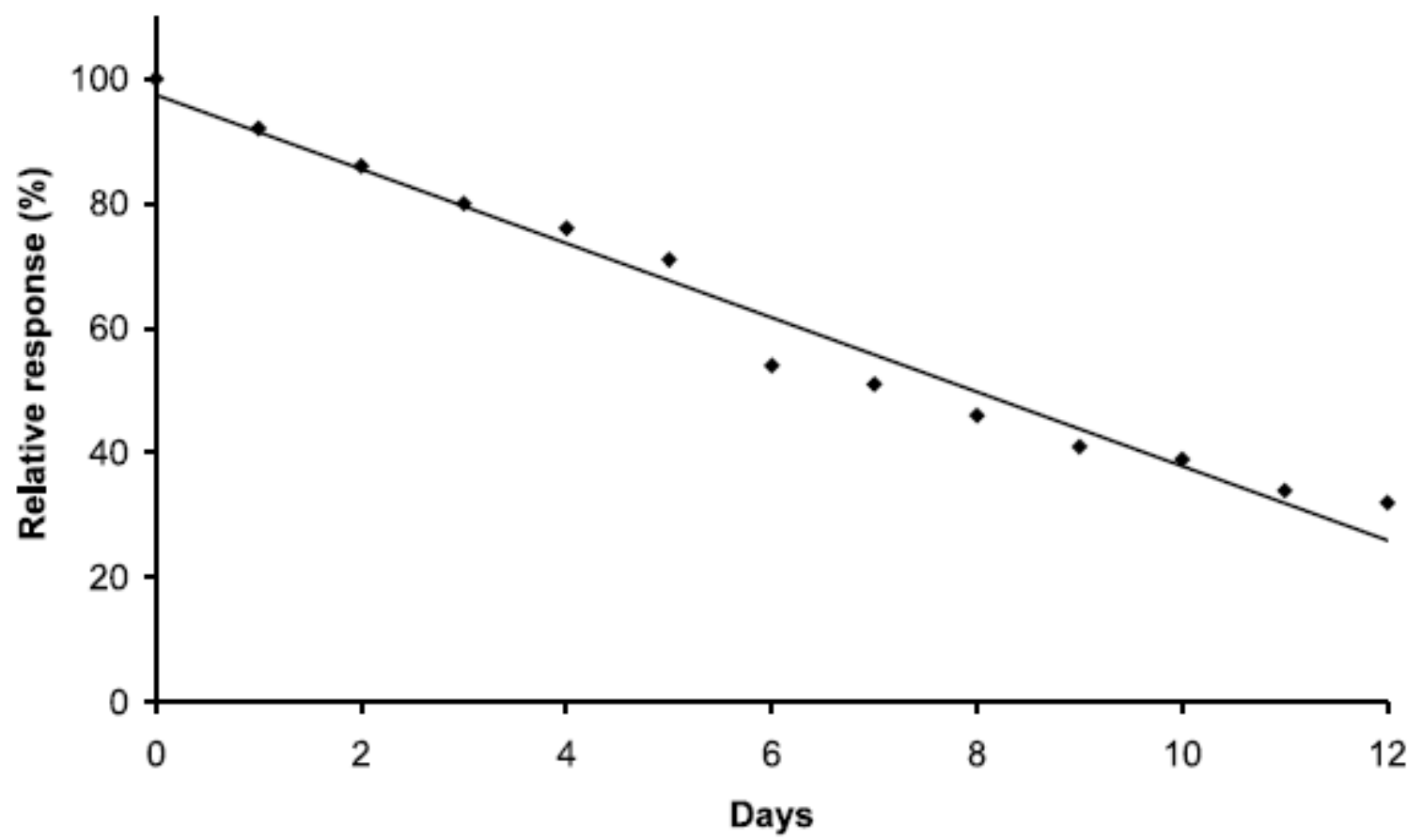

Figure 5: Long-term stability of a PEDT/PPO electrode using preparation method A. Conditions: $5 \mu \mathrm{M}$ catechol, $0.1 \mathrm{M}, \mathrm{pH} 6.5$ sodium phosphate buffer and $0.1 \mathrm{M} \mathrm{KCl}, 258 \mathrm{C},-/ 200 \mathrm{mV}$ vs. SCE. 


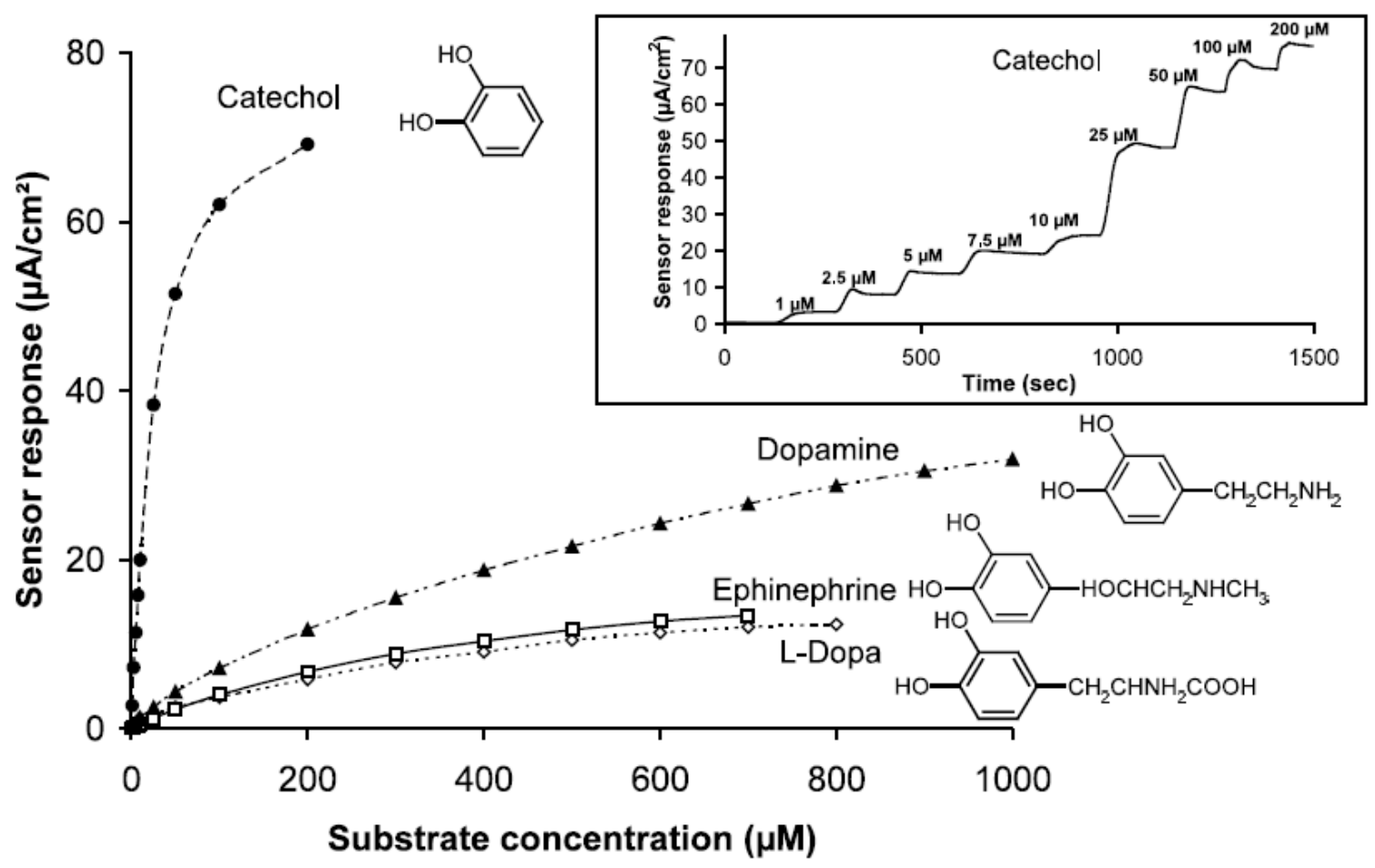

Figure 6: Dose/response curves of a PEDT/ PPO electrode using preparation method A for o-diphenol derivatives. Inset: Typical response of a PEDT/PPO electrode to catechol in an air-saturated buffer. Conditions: $0.1 \mathrm{M}, \mathrm{pH} 6.5$ sodium phosphate buffer and 0.1 M KCl, 25 8C, -/ $200 \mathrm{mV}$ vs. SCE.

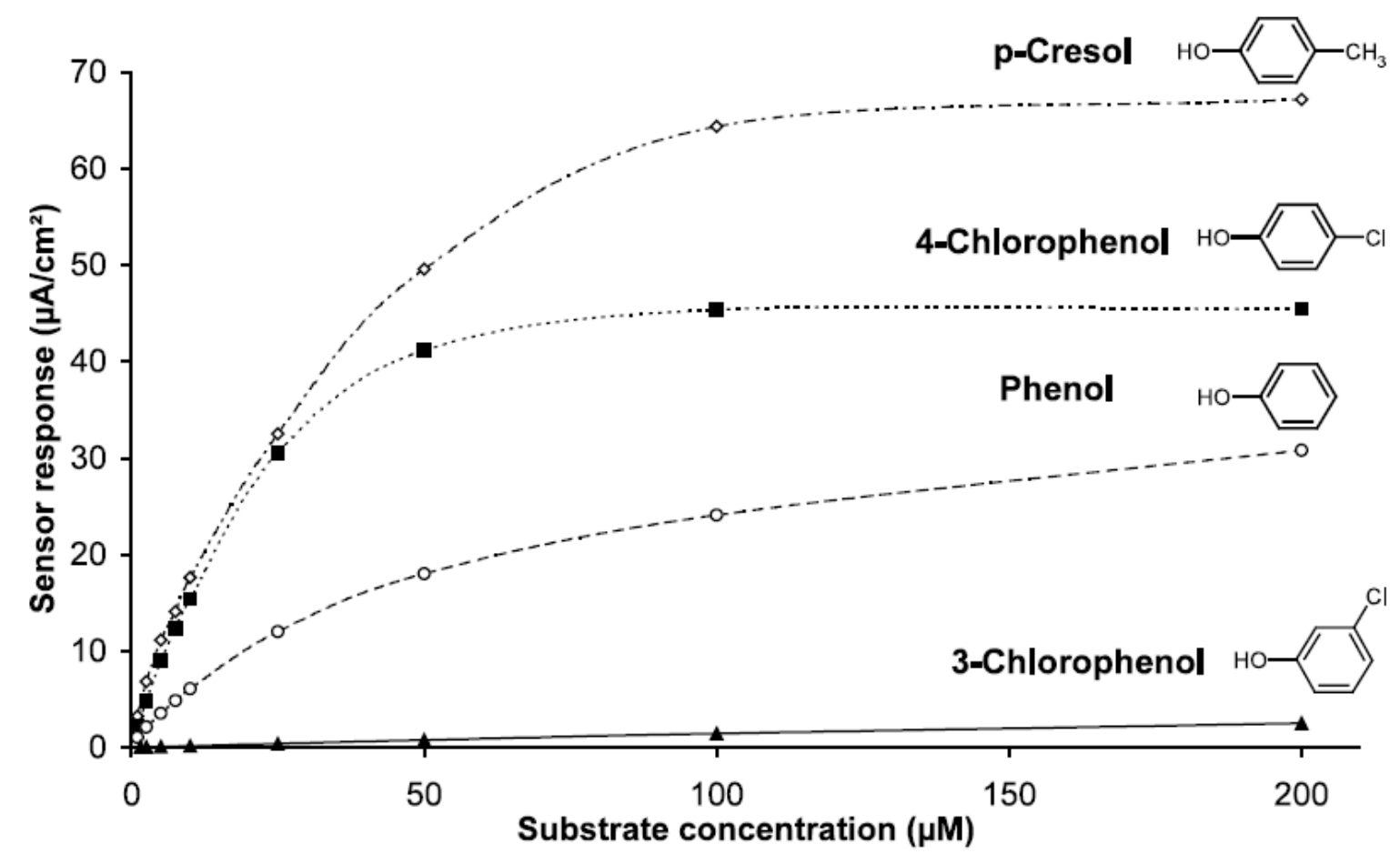

Figure 7: Dose-response curves of a PEDT/PPO electrode using preparation method A for mono-phenol derivatives. Conditions: $0.1 \mathrm{M}, \mathrm{pH} 6.5$ sodium phosphate buffer and $0.1 \mathrm{M} \mathrm{KCl}, 258 \mathrm{C},-/ 200 \mathrm{mV}$ vs. SCE. 


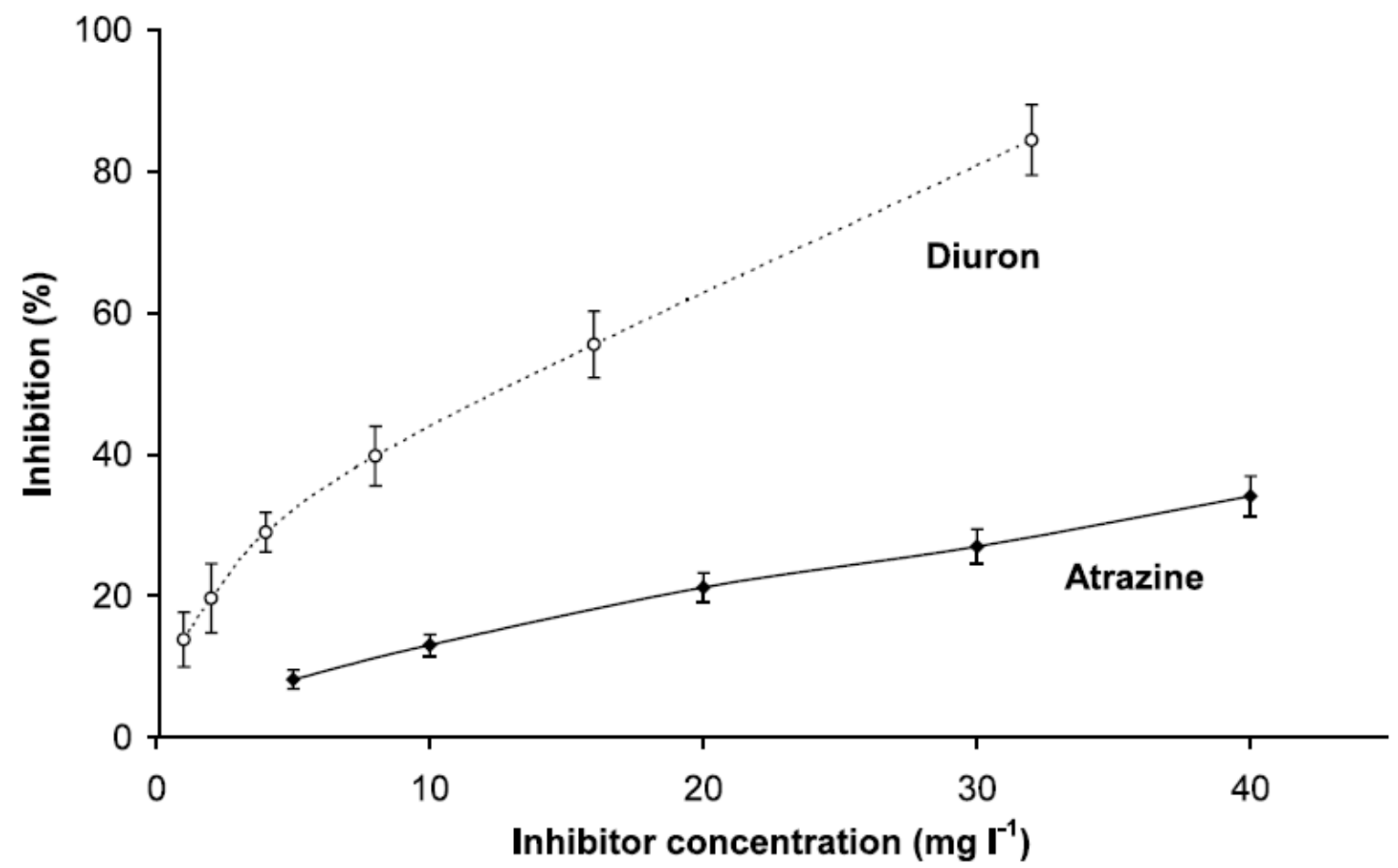

Figure 8: Inhibition effect of atrazine and diuron on the PEDT/ PPO electrode response to $25 \mu \mathrm{M}$ dopamine. Conditions: $0.1 \mathrm{M}, \mathrm{pH} 6.5$ sodium phosphate buffer and 0.1 M KCl, 25 8C, -/ $200 \mathrm{mV}$ vs. SCE.

\section{Tables}

Table 1: Sensitivity of phenol detection of different unmediated biosensors

\begin{tabular}{|l|l|l|l|}
\hline Immobilisation methods & $\begin{array}{l}\text { Sensitivity } \\
(\mathrm{mA} \mathrm{M}-1 \\
\mathrm{cm}-2)\end{array}$ & Time required for immobilisation procedure (min) & Reference \\
\hline Osmium hydrogel film & 9.6 & Several minutes & {$[27]$} \\
\hline Polypyrrole amphiphilic & 356 & 20 min of electropolymerisation & {$[21,26]$} \\
\hline Cryo-hydrogel & 180 & 39 h of freezing-/ thawing cycles & {$[42]$} \\
\hline Silica sol-/gel & 184 & 24 h at 4 8C=/ drying of the electrode & {$[35]$} \\
\hline PEDT film & 608 & 2 min & - \\
\hline
\end{tabular}

Table 2: Response characteristics of the tyrosinase biosensor to several phenolic compounds

\begin{tabular}{|l|l|c|c|c|}
\hline & Analyte & $\begin{array}{l}\text { Sensitivity } \\
(\mathrm{mA} \mathrm{M}-1 \mathrm{~cm}-2)\end{array}$ & $\begin{array}{l}\text { Linear up } \\
\text { to }(\mu \mathrm{M})\end{array}$ & $\begin{array}{l}\text { Limit of detection } \\
(\mathrm{nM})\end{array}$ \\
\hline Ortho-diphenol & Catechol & 1999 & 25 & - \\
\hline & Dopamine & 133 & 200 & 100 \\
\hline & Epinephrine & 56 & 200 & 500 \\
\hline & L-Dopa & 104 & 10 & 500 \\
\hline \multicolumn{5}{|l|}{} \\
\hline Mono-phenol & p-Cresol & 1759 & 10 & 5 \\
\hline & 4-Chlorophenol & 1538 & 10 & 5 \\
\hline & Phenol & 608 & 25 & 50 \\
\hline & 3-Chlorophenol & 13 & 100 & 500 \\
\hline
\end{tabular}

